\title{
Encephalitic Flaviviruses
}

\author{
Duncan R. Smith \\ Institute of Molecular Biosciences and Center for Emerging and Neglected Infectious \\ Diseases, Mahidol University \\ Thailand
}

\section{Introduction}

As defined by the Infectious Diseases Society of America, encephalitis is "the presence of an inflammatory process of the brain associated with clinical evidence of neurologic dysfunction" (Tunkel et al., 2008). In the absence of appropriate data, it is difficult to estimate the worldwide incidence of encephalitis, but in Southeast Asia Japanese encephalitis virus infections alone causes some 30,000 to 50,000 cases of encephalitis annually (Misra \& Kalita, 2010; Tsai, 2000) and causes of encephalitis include, but are not limited to, bacterial, viral, fungal and parasite infections as well as autoimmune and post infectious encephalitis where the encephalitis follows a usually mild viral infection or vaccine immunization and results from an inappropriate immune response. More than one hundred different infectious agents have been known to cause encephalitis, and while bacteria such as Mycobacterium tuberculosis (TB) and Bartonella henselae (the agent that causes cat scratch disease) are significant causes of encephalitis, viral infections are responsible for the majority of cases of infectious encephalitis. Viruses that can cause encephalitis include rabies virus, herpes simplex virus, enteroviruses including polioviruses, coxsackieviruses, echoviruses and a number of arboviruses (arthropod-borne viruses).

\begin{tabular}{|c|c|c|c|c|}
\hline & Primary vector species & $\begin{array}{c}\text { Probable } \\
\text { natural reservoir }\end{array}$ & Human disease & Encephalitis \\
\hline $\begin{array}{l}\text { Mammalian tick-borne virus group } \\
\text { Gadgets Gully virus } \\
\text { Kyasanur Forest disease virus } \\
\text { Langat virus } \\
\text { Louping ill virus } \\
\text { Omsk hemorrhagic fever virus } \\
\text { Powassan virus } \\
\text { Royal Farm virus } \\
\text { Tick-borne encephalitis virus }\end{array}$ & $\begin{array}{l}\text { Ixodes } \\
\text { Ixodes, Haemophysalis } \\
\text { Ixodes, Haemaphysalis } \\
\text { Ixodes } \\
\text { Dermacentor } \\
\text { Ixodes, Dermacentor, } \\
\quad \text { Haemaphysalis } \\
\text { Argas } \\
\text { Ixodes }\end{array}$ & $\begin{array}{l}\text { Birds } \\
\text { Monkeys, small mammals } \\
\text { Forest rats } \\
\text { Sheep, deer, birds } \\
\text { Mammals, rodents } \\
\text { Rodents, mustelids, } \\
\quad \text { lagomorphs } \\
\text { Rodents } \\
\text { Rodents }\end{array}$ & $\begin{array}{c}\text { No reports to date } \\
\text { Yes } \\
\text { Yes } \\
\text { Yes } \\
\text { Yes } \\
\text { Yes } \\
\begin{array}{c}\text { No reports todate } \\
\text { Yes }\end{array}\end{array}$ & $\begin{array}{l}\text { No } \\
\text { Possible } \\
\text { Yes } \\
\text { No } \\
\text { Yes } \\
\\
\text { Yes }\end{array}$ \\
\hline $\begin{array}{l}\text { Seabird tick-borne virus group } \\
\text { Kadam virus } \\
\text { Meaban virus } \\
\text { Saumarez Reef virus } \\
\text { Tyuleniy virus }\end{array}$ & $\begin{array}{l}\text { Rhipicephalus } \\
\text { Ornithodores } \\
\text { Ixodes } \\
\text { Ixodes }\end{array}$ & $\begin{array}{l}\text { Cloven hooved mammals, } \\
\text { rodents } \\
\text { Seabirds } \\
\text { Seabirds } \\
\text { Seabirds }\end{array}$ & $\begin{array}{l}\text { No reports to date } \\
\text { No reports to date } \\
\text { No reports to date } \\
\text { No reports to date }\end{array}$ & \\
\hline
\end{tabular}

Table 1. Tick-borne flavivirus species

There are over 500 known arboviruses, which predominantly belong to the Togaviridae, Bunyaviridae, Rhabdoviridae, Reoviridae and Flaviviridae families, and viruses that cause 
encephalitis in humans belong to all of these families. Encephalitis causing Togaviridae belong to the Alphavirus genus and include Ross River, Chikungunya and Western-, Easternand Venezuelan equine encephalitis viruses, while encephalitis causing viruses in the family Bunyaviridae belong to the Nairovirus (Crimean-Congo hemorrhagic fever virus), Phlebovirus (Rift Valley fever virus) and Orthobunyavirus (La Crosse virus) genera. Chandipura virus (family Rhabdoviridae, genus Vesiculovirus) has been associated with encephalitis, although there remains little further information. The family reoviridae contains 12 genera (Orthoreovirus, Orbivirus, Rotavirus, Coltivirus, Aquareovirus, Cypovirus, Fijivirus, Phytoreovirus, Oryzavirus, Mycoreovirus, Seadornavirus and Idnoreovirus) at least two of which contain arboviruses associated with encephalitis, namely the genera Coltivirus (Colorado Tick fever virus) and Seadornavirus (Banna virus). The family Flaviviridae contains only three genera (Hepacivirus, Pestivirus and Flavivirus) but the Flavivirus genus contains some of the most widespread and important arboviruses as well as the most important and widespread viruses associated with encephalitis.

\begin{tabular}{|c|c|c|c|c|}
\hline & Primary vector species & $\begin{array}{c}\text { Probable } \\
\text { natural reservoir }\end{array}$ & Human disease & Encephalitis \\
\hline $\begin{array}{l}\text { Aroa virus group } \\
\text { Aroa virus }\end{array}$ & Not known & Rodents & No reports to date & \\
\hline $\begin{array}{l}\text { Dengue virus group } \\
\text { Dengue virus } \\
\text { Kedougou virus }\end{array}$ & $\begin{array}{l}\text { Aedes } \\
\text { Aedes }\end{array}$ & $\begin{array}{l}\text { Primates } \\
\text { Primates (?) }\end{array}$ & $\begin{array}{l}\text { Yes } \\
\text { No reports to date }\end{array}$ & Occasional \\
\hline $\begin{array}{l}\text { Japanese encephalitis group } \\
\text { Cacipacore virus } \\
\text { Koutango virus } \\
\text { Japanese encephalitis virus } \\
\text { Murray Valley encephalitis virus } \\
\text { St. Louis encephalitis virus } \\
\text { Usutu virus } \\
\text { West Nile virus } \\
\text { Yaounde virus }\end{array}$ & $\begin{array}{l}\text { Culex } \\
\text { Culex } \\
\text { Culex } \\
\text { Culex } \\
\text { Culex } \\
\text { Culex } \\
\text { Culex } \\
\text { Culex }\end{array}$ & $\begin{array}{l}\text { Birds (?) } \\
\text { Rodents (?) } \\
\text { Migrating birds, } \\
\quad \text { domestic fowl, pigs } \\
\text { Birds, feral pigs (?) } \\
\text { Birds } \\
\text { Rodents, birds } \\
\text { Birds of family Corvidae, } \\
\quad \text { passerines } \\
\text { Birds (?) }\end{array}$ & $\begin{array}{l}\text { No reports to date } \\
\text { Yes } \\
\text { Yes } \\
\text { Yes } \\
\text { Yes } \\
\text { Yes } \\
\text { Yes } \\
\text { No reports to date }\end{array}$ & $\begin{array}{l}\text { No } \\
\text { Yes } \\
\text { Yes } \\
\text { Yes } \\
\text { No } \\
\text { Yes }\end{array}$ \\
\hline $\begin{array}{l}\text { Kokobera virus group } \\
\text { Kokobera virus }\end{array}$ & Culex & Macropods, Marsuplials & Yes & No \\
\hline $\begin{array}{l}\text { Ntaya virus group } \\
\text { Bagaza virus } \\
\text { Ilheus virus } \\
\text { Israel turkey meningoencephalomyelitis virus } \\
\text { Ntaya virus } \\
\text { Tembusu virus }\end{array}$ & $\begin{array}{c}\text { Culex } \\
\text { Psorophora, Aedes } \\
\text { Not known } \\
\text { Aedes (?) Culex (?) } \\
\text { Culex }\end{array}$ & \begin{tabular}{|l} 
Birds \\
Birds \\
Birds \\
Not known \\
Birds
\end{tabular} & $\begin{array}{c}\text { Yes } \\
\text { Yes } \\
\text { No reports to date } \\
\text { Yes } \\
\text { No reports to date }\end{array}$ & $\begin{array}{c}\text { Possible } \\
\text { Possible } \\
\text { No }\end{array}$ \\
\hline $\begin{array}{l}\text { Spondweni virus group } \\
\text { Zika virus }\end{array}$ & Aedes & Primates & Yes & No \\
\hline $\begin{array}{l}\text { Yellow fever virus group } \\
\text { Banzi virus } \\
\text { Bouboui virus } \\
\text { Edge Hill virus } \\
\text { Jugra virus } \\
\text { Saboya virus } \\
\text { Sepik virus } \\
\text { Uganda S virus } \\
\text { Wesselsbron virus } \\
\text { Yellow fever virus }\end{array}$ & $\begin{array}{l}\text { Culex } \\
\text { Anopheles } \\
\text { Aedes } \\
\text { Aedes } \\
\text { Phlebotomines } \\
\text { Ficalbia } \\
\text { Aedes } \\
\text { Aedes } \\
\text { Aedes }\end{array}$ & $\begin{array}{l}\text { Rodents } \\
\text { Primates } \\
\text { Wallabies, bandicoots } \\
\text { Bats } \\
\text { Rodents } \\
\text { Sheep (?) Humans (?) } \\
\text { Birds, Rodents (?) } \\
\text { Ruminants (Artiodactyla) } \\
\text { Primates }\end{array}$ & $\begin{array}{l}\text { Yes } \\
\text { No reports to date } \\
\text { Possible } \\
\text { No reports to date } \\
\text { No reports to date } \\
\text { Possible } \\
\text { No reports to date } \\
\text { Yes } \\
\text { Yes }\end{array}$ & $\begin{array}{l}\text { No } \\
\text { No } \\
\text { No } \\
\begin{array}{c}\text { Possible } \\
\text { No }\end{array}\end{array}$ \\
\hline
\end{tabular}

Table 2. Mosquito-borne flavivirus species

A total of 53 species of flaviviruses are listed in the latest version of the International Committee on Taxonomy of Viruses Master species list version 9 (ICTV, 2011). A further 23 
viruses are considered to be strains belonging to the 53 species, while another two viruses (Cell fusing agent virus and Tamana bat virus) are considered tentative species in the genus (ICTV, 2011). The genus Flavivirus is divided into three clusters, the mosquito-borne cluster, the tick-borne cluster and the "no known arthropod vector" cluster. All flaviviruses of human importance belong to the mosquito-borne or tick-borne clusters. While flaviviruses that cause human disease are found in the "no known arthropod vector" cluster, these have not yet been responsible for significant outbreaks of human disease. Classification of flaviviruses was originally based upon classical studies using cross-neutralization tests, with viruses that induce cross reacting antibodies being placed into the same "serogroup". In recent times however grouping of flaviviruses has been predominantly based upon genetic analysis with viruses being placed into groups based upon sequence analysis. For the majority of flaviviruses, these groupings are synonymous, although some differences do occur. For example the Cacipacoré virus which was originally considered an ungrouped flavivirus based on cross neutralization tests is now considered part of the Japanese encephalitis group based upon sequence data and phylogenic analysis.

The tick-borne cluster of flavivirus is commonly divided into the mammalian tick-borne virus group and the seabird tick-borne virus group (see Table 1), while the mosquito -borne flaviviruses are commonly segregated into 7 groups (See Table 2). The no known arthropod vector group currently consists of 12 virus species, divided into 3 groups (See Table 3 ).

\begin{tabular}{|c|c|c|c|c|}
\hline & Primary vector species & $\begin{array}{c}\text { Probable } \\
\text { natural reservoir }\end{array}$ & Human disease & Encephalitis \\
\hline $\begin{array}{l}\text { Entebbe virus group } \\
\text { Entebbe bat virus } \\
\text { Yokose virus }\end{array}$ & $\begin{array}{l}\text { Unknown } \\
\text { Unknown }\end{array}$ & $\begin{array}{l}\text { Bats } \\
\text { Bats }\end{array}$ & $\begin{array}{l}\text { No reports to date } \\
\text { No reports to date }\end{array}$ & \\
\hline $\begin{array}{l}\text { Modoc virus group } \\
\text { Apoi virus } \\
\text { Cowbone Ridge virus } \\
\text { Jutiapa virus } \\
\text { Modoc virus } \\
\text { Sal Vieja virus } \\
\text { San Perlita virus }\end{array}$ & $\begin{array}{l}\text { Unknown } \\
\text { Unknown } \\
\text { Unknown } \\
\text { Unknown } \\
\text { Unknown } \\
\text { Unknown }\end{array}$ & $\begin{array}{l}\text { Rodents } \\
\text { Rodents } \\
\text { Rodents (?) } \\
\text { Rodents (?) } \\
\text { Rodents } \\
\text { Rodents }\end{array}$ & $\begin{array}{l}\text { Possible } \\
\text { No reports to date } \\
\text { No reports to date } \\
\text { Possible } \\
\text { No reports to date } \\
\text { No reports to date }\end{array}$ & Possible \\
\hline $\begin{array}{l}\text { Rio Bravo virus group } \\
\text { Bukalasa bat virus } \\
\text { Carey Island virus } \\
\text { Dakar bat virus } \\
\text { Montana myotis leukoencephalitis virus } \\
\text { Phnom Penh bat virus } \\
\text { Rio Bravo virus }\end{array}$ & $\begin{array}{l}\text { Unknown } \\
\text { Unknown } \\
\text { Unknown } \\
\text { Unknown } \\
\text { Unknown } \\
\text { Unknown }\end{array}$ & $\begin{array}{l}\text { Bats } \\
\text { Bats } \\
\text { Bats } \\
\text { Bats } \\
\text { Bats } \\
\text { Bats }\end{array}$ & $\begin{array}{c}\text { No reports to date } \\
\text { No reports to date } \\
\text { No reports to date } \\
\text { No reports to date } \\
\text { No reports to date } \\
\text { Possible }\end{array}$ & No \\
\hline
\end{tabular}

Table 3. No known arthropod vector flavivirus species

As with all arboviruses, arboviral flaviviruses are maintained in natural cycles in which they multiply in a blood sucking arthropod such as a mosquito or tick and are then transmitted to a vertebrate host via the saliva when the insect takes a blood meal. Replication of the virus in the vertebrate host causes viremia of a sufficient level to allow infection of a naïve mosquito as it feeds. When infected, the arthropod becomes infected for life while in contrast the vertebrate host normally undergoes an acute but normally self limiting infection. In natural transmission cycles neither the arthropod vector nor the vertebrate suffer significant consequences of the infection. With the exception of urban cycles of yellow fever and dengue fever viruses, humans are not the principal amplifying host and infection in humans occurs when the vector feeds on humans as an alternate to its normal vertebrate 
host. In these cases infection is normally a dead end for virus transmission as the disease is usually of a low titer viremia, although the consequences may be significant for the human host. The "no known arthropod vector group" of flaviviruses remains poorly understood. They are predominantly associated with either rodents or bats, and the ecology of their transmission remains largely undefined. There are scattered reports of possible infections of humans, usually by direct infection, although there is little confirmatory evidence linking the pathogen with the disease. These viruses are however of significant interest given their potential for emerging into the human population.

\section{The encephalitic flaviviruses}

\subsection{Epidemiology}

\subsubsection{The Japanese encephalitis group.}

The Japanese encephalitis group of the mosquito-borne flavivirus cluster consists of 8 virus species (Table 2) of which 4 viruses (Japanese encephalitis virus, Murray Valley encephalitis virus, St. Louis encephalitis virus and West Nile virus) have been consistently associated with encephalitis in cases of human infection.

\subsubsection{Japanese encephalitis virus}

Japanese encephalitis is one of the most important encephalitic diseases worldwide, resulting in some 35,000 to 50,000 deaths annually (Misra \& Kalita, 2010; Tsai, 2000). Humans can become infected as a consequence of the bite of an infected mosquito, although evidence suggests that humans are not a natural host, but rather a dead-end host for Japanese encephalitis virus infection (Rosen, 1986). Naturally Japanese encephalitis virus is transmitted in an enzootic cycle among birds, particularly ardeid wading birds, and mosquitoes, principally Culex tritaeniorhynchus (Halstead \& Jacobson, 2003) and Culex quinquefasciatus. The geographic distribution of Japanese encephalitis virus is mainly in the Asian region including India, China, and all of South-East Asia, although outbreaks have also been reported in Australia. Pigs have become an important host for maintaining, amplifying and spreading Japanese encephalitis virus as they undergo a long lasting viremia upon infection and are a preferred feeding source for Culex tritaeniorhynchus. The commercial pig farm industry both provides a source of susceptible animals in endemic areas, as well as potentially spreading the disease through the transport of infected animals. In Southeast Asian countries Japanese encephalitis virus is the leading reported cause of acute encephalitis in children, accounting for approximately $40 \%$ of cases (Solomon et al., 2002; Srey et al., 2002).

\subsubsection{Murray Valley encephalitis virus}

Murray Valley encephalitis virus (sometimes called Australian encephalitis) is spread primarily by Culex annulirostris, and is believed to be endemic only in Australia and Papua New Guinea. Since the last major outbreak in Australia in 1974, which infected nearly 60 patients, only sporadic outbreaks have been recorded.

\subsubsection{St. Louis encephalitis virus}

St. Louis encephalitis virus is distributed over much of the Americas, and is found in Canada (Ontario), the United States (especially in western states and in the southeast), Trinidad, Jamaica, Panama, Brazil, and Argentina. In North America approximately 25-50 individuals are symptomatically infected each year and significant outbreaks affecting up to 
800 people per 100,000 occur every 5 to 15 years in the Americas. The last major epidemic recorded was in 1990 in Florida which resulted in 11 deaths. Passeriforme and Columbiforme birds are believed to be the major reservoir species, and transmission is by Culex spp mosquitoes.

\subsubsection{West Nile virus}

West Nile virus is the most wide spread flavivirus with a worldwide distribution including Africa, Asia, Europe, and North America (Bakonyi et al., 2005). West Nile virus is naturally maintained in a cycle between bird feeding mosquitoes and wild animals, mainly birds. The natural cycle primarily involves the Culex species of mosquitoes in particular Culex pipiens, Culex quinquefasciatus and Culex restuans which are the most important West Nile virus vectors. A broad range of mammalian species are found to be susceptible to natural infection with West Nile virus following infectious mosquito bite(s) and includes humans, horses, cats, rabbits, skunks, squirrels, chipmunks, and two species of bats (Marfin et al., 2001). Although initially West Nile virus was considered to have a minor human health impact, West Nile virus epidemics have become widely distributed causing several hundreds of reported cases in Romania in 1996 (Tsai et al., 1998), Russia in 1999 (Platonov et al., 2001), and Israel in 2000 (Chowers et al., 2001). West Nile virus has also been a significant cause of human illness in the United States. By the end of 2002, West Nile virus activity had been identified in 44 states and the District of Columbia resulting in reports of over 4,000 human cases of West Nile disease (including several thousand cases of meningoencephalitis cases and almost 300 deaths). Reported deaths were also recorded for wild animals including 16,741 dead birds and 14,571 equine cases (Centers for Disease Control and Prevention (CDC), 2003). Phylogenetic analyses have shown 2 distinct lineages of West Nile virus strains which were isolated in different geographic regions: I and II (Berthet et al., 1997; Lanciotti et al., 1999; Savage et al., 1999). Lineage I has a wide distribution including Africa, Asia, Europe, and North America and is associated with all the outbreaks of human and equine diseases. Lineage II is restricted to endemic enzootic infections in Africa and has not been associated with human encephalitis (Berthet et al., 1997).

\subsubsection{The tick-borne encephalitis group}

The tick-borne encephalitis group consists of two main subgroups (the mammalian tickborne virus group and the seabird tick-borne virus group), with human pathogens being limited to the mammalian tick-borne group (Table 1). Three virus species within this group have a consistent association with encephalitis, namely Louping ill virus, Powassan virus and Tick-borne encephalitis virus. The position of the Kadam virus within the seabird tickborne cluster remains somewhat controversial, but this virus has not been associated with significant levels of human infection nor encephalitis, and as such is not discussed further in this article. Similarly Langat virus is naturally attenuated and does not seem to be associated with human disease under natural conditions. While there are reports of Langat associated encephalitis in humans, these have occurred solely in large scale vaccination trials attempting to use Langat virus to protect against Tick-borne encephalitis virus infection in Russia.

\subsubsection{Louping ill virus}

Louping ill virus occurs mainly in the British Isles, where sheep are the most important reservoir host for this virus, but amplification can also occur in grouse and mountain hares which have been implicated as maintenance hosts via non-viremic transmission between co- 
feeding ticks. The principal vector for transmission is the tick Ixodes ricinus, although other species of tick including Rhipicephalus appendiculatus, Ixodes persulcatus and Haemaphysalis anatolicum are capable of transmitting the virus. Louping ill virus produces a symptomatic disease in sheep which may have a neurological component including encephalitis. Fewer than 100 cases of Louping ill infection of humans have been reported in the British Isles, most commonly in agricultural workers, although a number of cases of laboratory based infection have been reported. While direct tick transmission to humans is a possibility, there are few reliable reports of transmission by this route, and infection may arise predominantly through contact with sick animals or infected tissues or fluids.

\subsubsection{Powassan virus}

Only between 20 and 50 cases of human Powassan virus infection have been reported since the first identified case of a boy who died from infection with the virus in Powassan, Ontario in 1958. The virus is widely distributed in North America in both Canada and in the United States, and reports have identified Powassan virus in locations in southeastern Siberia. The virus is maintained in transmission cycles that include several species of small wild mammals including the woodchuck (Marmota monax), squirrels, chipmunks and deer mice and several species of Ixodes ticks. In eastern and central Canada, the transmission cycle between the woodchuck and the tick Ixodes cookei may be of particular importance.

\subsubsection{Tick-borne encephalitis virus}

Tick-borne encephalitis virus is one of the most important tick-borne flaviviruses causing a serious acute central nervous system infection and the distribution of this disease stretches from seven countries in northern Asia to central Asia and 25 Western European countries (Charrel et al., 2004). Naturally, Tick-borne encephalitis virus is maintained in a cycle involving ticks and wild vertebrate hosts. While several different species of tick have been found to be biologically competent to transmit Tick-borne encephalitis virus in the laboratory, in nature, because of specific ecological limiting factors, only Ixodes ricinus in Europe, and Ixodes persulcatus and Haemaphysalis concinna in Russia, appear to play a significant role in the virus maintenance (Labuda \& Randolph, 1999). There are three subtypes of Tick-borne encephalitis virus, the European (also known as Central European encephalitis virus), Siberian (also known as west-Siberian encephalitis virus) and Fareastern (also known as Russian Spring/Summer encephalitis virus), in which the degrees of virulence are different (Mansfield et al., 2009). Transmission of Tick-borne encephalitis virus through raw milk or cheese from goats, sheep and cows was previously responsible for 10 to $20 \%$ of cases of Tick-borne encephalitis virus transmission in central Europe.

\subsection{Pathogenesis and clinical features}

All of the encephalitic flaviviruses have several features in common and they all raise a significant immune response. The initial response is generally a non-specific innate response that occurs within the first few days after infection, and pathogen specific humoral (antibody) and cell mediated immunity begin four to seven days after infection. The antibody response raised is frequently extremely broad and cross reactive with other flaviviruses and generates lifelong immunity towards the homotypic virus as well as potentially partial protection against other flaviviruses. With each of the encephalitic flaviviruses, symptomatic infections are greatly outnumbered by asymptomatic infections, and symptomatic infections generally generate a broad spectrum of responses in patients ranging from a mild disease typically characterized by fever and headache to severe 
encephalitis or meningitis leading often to coma and death. The broad range of responses to the infecting pathogen suggests a complex interplay between host and viral factors that remains largely unexplained. Where encephalitis is a component of the disease pathology, long term neurological deficit is common. The underlying mechanism by which some flaviviruses, but not others, cause encephalitis is still the subject of considerable investigation. Where flavivirus infection does lead to encephalitis, the mechanism by which the virus crosses the blood brain barrier remains to be fully elucidated, and several mechanisms have been proposed. Studies of neurotropism in a hamster model of St. Louis encephalitis virus infection have shown the importance of axonal transport through olfactory neurons (Monath et al., 1983), thus evading the blood brain barrier. However, postmortem studies on patients who died from Japanese encephalitis virus infection showed diffuse infection throughout the brain, indicating a hematogenous route of entry (Desai et al., 1995; Johnson et al., 1985). Infection of parenchyma may therefore result from either simple diffusion from vascular endothelial cells at sites where the integrity of the blood brain barrier has been compromised due to trauma, or through replication of the virus in the endothelial cells of brain capillaries, and release of the virus into the brain. Alternatively, some evidence has suggested a role for overproduction of inflammatory cytokines as a consequence of activation of the Toll-like receptor (TLR) 3 as causative in weakening the blood brain barrier in West Nile virus infections (Wang et al., 2004). However, a simple increase in permeability of the blood brain barrier seems not to be the primary determinant of lethality in animal model systems (Morrey et al., 2008), suggesting that additional factors need to be elucidated. Whether all encephalitic flaviviruses use the same mechanism, or indeed whether a specific virus utilizes several pathways remains to be determined.

\subsubsection{The Japanese encephalitis virus group}

\subsubsection{Japanese encephalitis virus}

Population based studies in areas with endemic Japanese encephalitis have estimated the ratio of overt: inapparent Japanese encephalitis virus infections as approximately 1:250 (Gajanana et al., 1995). Where symptomatic infection occurs, symptoms start some five to 15 days after infection. Mild infections are generally characterized by a fever and headaches while more severe disease is characterized by nausea and vomiting, neck stiffness, stupor, disorientation, convulsions and paralysis. While a proportion of patients make a rapid and spontaneous recovery, up to $30 \%$ of patients admitted to hospital with Japanese encephalitis die. For nonfatal cases of Japanese encephalitis, approximately $50 \%$ of the survivors suffer from severe neurological sequelae, and even those who have been classed as having "good recovery" have evidence of neurological damage (Kumar et al., 1993; Solomon et al., 2000). There is some evidence that Japanese encephalitis virus may establish a latent infection in some patients that can lead to recurrence of symptoms many months later (Sharma et al., 1991).

\subsubsection{Murray Valley encephalitis virus}

Serological surveys suggest that only 1 in 1000 infections with Murray Valley Encephalitis virus result in a symptomatic disease. Where a symptomatic infection does occur, symptoms arise some one to four weeks after exposure to the virus and may include headache, nausea, vomiting, myalgia and a rash. In a proportion of symptomatic cases lethargy, confusion, convulsions and fits may occur indicative of neurological involvement and coma and death may follow. Up to $25 \%$ of cases of symptomatic Murray Valley encephalitis infection are fatal, and survivors may show long term neurological deficits. 


\subsubsection{St. Louis encephalitis virus}

As with other flavivirus infections, infections with St. Louis encephalitis virus are generally asymptomatic, with an inapparent: apparent infection ratios of between 16:1 and 425:1. The incubation period between infection and the onset of symptoms is believed to be 21 days, and symptomatic infection usually results in a mild disease characterized by headache, tiredness and dizziness, sometimes with nausea and vomiting. Severe disease with neurologic involvement including encephalitis or aseptic meningitis is rare, and more commonly found in older adults. Long term disability and death can occur, and the disease is fatal in up to $10 \%$ of patients.

\subsubsection{West Nile virus}

Most infections with West Nile virus are asymptomatic and symptomatic West Nile fever occurs in only $20-30 \%$ of cases of infection. West Nile fever is a flu-like illness which develops 3 - 14 days post infection and is characterized by fever, headache, back pain, fatigue, arthralgia and myalgia (Hayes et al., 2005) with symptoms sometimes persisting for several weeks. A maculopapular rash occurs in about $50 \%$ of cases. Neurological involvement occurs in less than $1 \%$ of infections, and is characterized by encephalitis in $60 \%$ of cases, and meningitis in $40 \%$ of cases. Neurological involvement can result in long term cognitive and neurological deficits.

\subsubsection{The tick-borne encephalitis group}

\subsubsection{Louping ill virus}

Given the small number of cases of Louping ill virus infection recorded, accurate clinical data is somewhat scarce. A four to seven day incubation period is believed to occur after infection before the onset of symptoms. Evidence suggests that the disease evinces with a mild fever, headache and tiredness which may be mistaken for flu, and serological studies in abattoir workers suggest a greater degree of exposure to the virus than symptomatic cases would suggest. In some infections the mild symptoms maybe the only pathological expression of the disease, however, in other infections after an apparent remission period of approximately one week, the fever recurs together with neurologic complications which can include meningoencephalitis or paralytic poliomyelitis. Even with the severe form of Louping ill virus infection, death is rare, and although convalescence maybe prolonged, there are no apparent long term neurological deficits.

\subsubsection{Powassan virus}

While an extremely limited number of cases of infection with Powassan virus have been recorded, serological evidence suggests that large numbers of people have been exposed to the virus. Serological surveys in Ontario between 1959 and 1961 suggested an average yearly exposure of approximately $2 \%$ of the population, suggesting that symptomatic infections with Powassan virus are significantly outnumbered by asymptomatic infections. Where symptomatic infection occurs, an estimated 8 to 34 days after infection, early symptoms include headache, lethargy and disorientation, while in the later progression of the disease, encephalopathy is extremely common. The case fatality rate for Powassan virus infection is believed to be 10 to $15 \%$, but severe, long term neurological sequelae are present in up to $50 \%$ of the survivors (Ebel, 2010; Gholam et al., 1999). 


\subsubsection{Tick-borne encephalitis virus}

An estimated $90 \%$ of cases of infection with Tick-borne encephalitis virus are believed to be asymptomatic or to result in a non-specific illness. Symptomatic disease, which may last from two to four days is characterized by a non-specific flu like disease with fever, headache, myalgia and vomiting and occurs after an incubation period of one to two weeks, although the range of onset of symptoms extends between two days and one month. Reports suggest infection through raw milk and milk products may lead to a faster onset of symptoms. In approximately one third of cases the disease presents as a biphasic disease and after an approximately one week (range 1 to 20 days) asymptomatic period the second phase of the disease occurs. The second phase of the disease is heralded by the onset of a high fever coupled with central nervous system involvement and involves symptoms of meningitis (fever, headache, stiff neck) or encephalitis (drowsiness, confusion, sensory disturbances, paralysis) or meningoencephalitis. Encephalitis is more commonly found in adults over the age of 40 , while children are more likely to experience meningitis. Infection with Tick-borne encephalitis virus may result in mortality or long-term neurological sequelae in $35-58 \%$ of patients. The fatality rate associated with clinical infection is $0.5-20 \%$ (World Health Organization, 2006), although the Far Eastern subtype is generally associated with a higher mortality rate ( 5 to $20 \%$ fatality rate) than the European subtype (1-2\%). As with Japanese encephalitis virus, some data suggests that the Tick-borne encephalitis virus may be able to establish latent infections leading to the recurrence of symptoms after a long remission period (Ogawa et al., 1973).

\subsection{Flavivirus life cycle}

Flaviviruses are spherical viruses some $40-60 \mathrm{~nm}$ in diameter consisting of three structural proteins, Envelope (E), Membrane (M) and Capsid (C) and a single stranded (+) sense RNA molecule of approximately $11 \mathrm{~kb}$. The RNA contains both $5^{\prime}$ and $3^{\prime}$ untranslated regions and is usually not polyadenylated (although some strains of tick-borne encephalitis may contain a poly(A) tract) and encodes the three structural proteins (C, E and pre-M), as well as seven non-structural proteins (NS1, NS2A, NS2B, NS3, NS4A, NS4B and NS5) and is translated as a single open reading frame and processed by host and virally encoded proteases (Henchal \& Putnak, 1990; Perera \& Kuhn, 2008). The viruses contain a significant amount of lipid (15$20 \%$ by weight) that is similar in content to the host cell membranes (Russell et al., 1980).

Flaviviruses predominantly enter into both insect and mammalian cells through endocytosis into clathrin coated pits following binding to a specific receptor or receptors. While clathrin mediated endocytosis has been clearly established for a number of different flaviviruses through studies using biochemical and genetic characterization methods in a wide range of cell types, characterization of the receptor or receptor complexes used in the initial binding remains much more poorly characterized, and evidence suggests that virus entry may be cell type specific. However, it is clear that it is an interaction between the flavivirus envelope (E) glycoprotein that mediates the interaction of the virus with the host cell and the flavivirus E glycoprotein is believed to contain the components responsible for several important viral functions including target cells binding, induction of protective immunity, mediation of membrane fusion and virus assembly (Chang, 1997; Heinz, 1990; Kimura \& Ohyama, 1988; Klasse et al., 1998). The E protein is highly conserved amongst all flaviviruses and shares common features. Conservation of cysteine residues and similar hydrophobicity profiles suggest a common folded structure of the E protein for all 
flaviviruses. Recently high resolution flavivirus E protein crystal structures of dengue virus serotype 2 (Modis et al., 2003) and tick-borne encephalitis (Rey et al., 1995) have shown their close relationship in overall dimeric structure, protein folding and a similar set of six disulfide bonds (Modis et al., 2003; Rey et al., 1995). The approximately 55 to $60 \mathrm{kDa} \mathrm{E}$ protein contains 494 to 501 amino acids folded into three distinct structural and functional domains; domains I, II and III which correlate well with the previously defined antigenic domains C, A, and B. (Chang, 1997; Heinz et al., 1983; Roehrig et al., 1983). Domain I and III (C and B) contain predominately subcomplex- and type-specific epitopes, whereas domain II (A) the dimerization domain, contains broadly flavivirus-cross-reactive epitopes and also subtype-specific epitopes (Mandl et al., 1989). The flavivirus domain III has been shown to participate in virus attachment through its interaction with a cellular receptor (Chu et al., 2005; Crill \& Roehrig, 2001; Hung et al., 2004; Hurrelbrink \& McMinn, 2001; Volk et al., 2004). The participation of domain III in cell entry appears to involve the presence of a putative receptor binding loop (Modis et al., 2003) and a heparan sulphate binding site (Chen et al., 1997; Mandl et al., 1989; Twiddy et al., 2002; Wu et al., 2004) including the membrane fusion peptides (Allison et al., 2001). Apparently the flavivirus E glycoprotein is a crucial determinant of the host range, tissue tropism, and virulence of the virus (Crill \& Chang, 2004; Mandl, 2005). After virus entry into the target cell, the acid environment of the endosome vesicle triggers conformational changes in the virions and fusion of viral and cell membranes and particle disassembly occur (Dimitrov, 2004; Marsh, 1984).

The non-structural proteins then initiate the replication of the viral genome in close association with the ER, and the newly synthesized RNA is packaged by the C protein forming a nucleocapsid complex. The nucleocapsids bud from the ER and become enveloped by a lipid membrane carrying with it associated envelope (E) and the premembrane (prM) proteins which have formed initially into prM/E heterodimers and subsequently these heterodimers associate into trimers (Kuhn et al., 2002; Perera \& Kuhn, 2008). The newly assembled particle is in an immature form, in which the prM/E heterodimers project from the surface as 60 trimeric spikes and has a diameter of approximately 600 Angstroms (Li et al., 2008; Yu et al., 2009). After budding from the ER, the immature viruses transit the secretory pathway, where the prM protein is cleaved by the cellular furin protease after a major conformational change induced by the acidic environment of the trans-Golgi network resulting in exposure of a furin cleavage site (Li et al., 2008; Yu et al., 2009). In the slightly acidic $\mathrm{pH}$ of the trans-Golgi network the cleaved

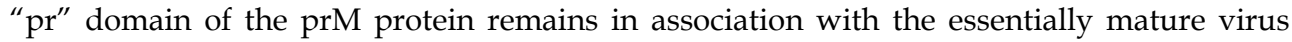
particle, preventing premature membrane fusion inside the cell. Exposure to a neutral $\mathrm{pH}$ upon virion exposure to the extracellular milieu induces dissociation of the "pr" peptide from the now mature virion (Yu et al., 2009).

\subsection{Current and future vaccine development}

The development of vaccines to protect against infections by members of the flavivirus genus has been extremely uneven. It is of note that the vaccine against the prototype flavivirus, Yellow fever virus, the causative agent of yellow fever, is one of the most successful live attenuated vaccines, with the currently used YF-17D derivatives capable of inducing a protective level of neutralizing antibodies in $99 \%$ of recipients within 30 days from a single dose (Monath, 2001). In contrast, the effort to develop an effective live attenuated vaccine or vaccines against dengue virus remain incomplete, despite more than 
60 years of investigation since the pioneering studies of Sabin and Schlesinger (Sabin \& Schlesinger, 1945). For the flaviviruses that are associated with encephalitis, the picture is somewhat more promising.

\subsubsection{Japanese encephalitis virus}

For the most significant flavivirus causing encephalitis, Japanese encephalitis virus, vaccines have been available since the 1950s. The original vaccine widely distributed in much of Asia was a formalin inactivated whole virus formulation grown in mouse brain using either the Nakayama or Beijing-1 strains (Halstead \& Thomas, 2010). Despite acceptable protection levels after one, two or three vaccination doses and a significant decrease in the number of cases of Japanese encephalitis in countries where the vaccine was widely used (Solomon, 2004; Solomon et al., 2000), possibly unfounded concerns as to adverse reactogenicity of this formulation (Halstead \& Thomas, 2010) led to discontinuation of production of this vaccine. The mouse brain produced vaccine was developed in Japan and used in much of Asia for indigenous populations as well as used for vaccination of travelers to endemic areas. China however developed its own, cell culture produced, whole virus inactivated vaccine for Japanese encephalitis based on culture of the P-3 or Beijing-3 strain of Japanese encephalitis in primary hamster kidney (PHK) cells, which was later superseded by the production of a live attenuated vaccine, SA14-14-2. This vaccine has been reported to induce excellent, long lived protection after a single dose administration and is currently distributed in China and several other Asian countries. The SA14-14-2 vaccine strain was the starting point for development of a further, whole virus formalin inactivated vaccine IXARO (IC51) developed originally by the Walter Reed Army Institute of Research. This vaccine is produced in Vero (African green monkey kidney) cells and induces high levels of protection after two or three doses. It is expected that this vaccine will be widely distributed (Halstead \& Thomas, 2010). One further Japanese encephalitis vaccine candidate is currently on the brink of being widely marketed and distributed. This vaccine, the so called IMOJEV (JE-CV and previously called ChimeriVax-JE) vaccine is a live attenuated recombinant vaccine based upon the exceedingly well characterized YF-17D backbone, with the prM and E coding sequences from Japanese encephalitis virus replacing the equivalent YF-17D sequences. This vaccine offers levels of protection apparently equivalent or greater than other existing vaccines with a single dose administration generating protective antibody levels in $95 \%$ (children) or 99\% (adults) of recipients by 1 month post-administration (Halstead \& Thomas, 2010). Overall, with three effective and apparently safe vaccines either being distributed or in the process of being distributed, the outlook for control of Japanese encephalitis is promising.

\subsubsection{West Nile virus}

There is currently no licensed vaccine to protect against West Nile virus infection for use in humans although five vaccines are available for vaccination of horses. Two of these vaccines, the West Nile-Innovator ${ }^{\mathrm{TM}}$ (Fort Dodge Animal Health) and the BoehringerIngelheim Vetera ${ }^{\mathrm{TM}}$ vaccine consist of whole inactivated virus. In both cases the vaccine is derived from an equine isolate of West Nile virus. The third vaccine available (Prevenile ${ }^{\mathrm{TM}}$, Intervet/Schering-Plough Animal Health) is a chimeric vaccine using the Yellow fever vaccine YF-17D backbone and the pre-membrane and envelope proteins of West Nile virus, although a recall notice is currently in effect on this vaccine due to reports of adverse 
reactions (http://www.prevenile.com/PDF/PreveNile\%20Letter.pdf; accessed 17/02/2011). The fourth horse vaccine for West Nile virus (Recombitek ${ }^{\mathrm{TM}}$, Merial) is a recombinant canarypox vector containing the pre-membrane and envelope proteins of West Nile virus, while the fifth vaccine (West Nile- Innovator ${ }^{\circledR}$ DNA, Fort Dodge Animal Health) is a DNA vaccine encoding the West Nile virus prM and E proteins.

Perhaps unsurprisingly, development of a human vaccine largely follows from the progress made with equine vaccines. A phase II trial of a chimeric YF-17D backbone with the West Nile pre-membrane and envelope proteins has been undertaken (Biedenbender et al., 2011). This vaccine largely follows the equine Prevenile vaccine strategy, but includes three mutations in the E protein predicted to reduce neurovirulence, and results from the Phase II study suggest that the construct is highly immunogenic and well tolerated (Biedenbender et al., 2011). Similarly, a Phase I trial of DNA vaccine encoding the pre-membrane and envelope proteins of the NY99 strain of West Nile virus was completed in 2007 (Martin et al., 2007).

Other potential vaccine candidates include a live attenuated Schwarz strain of measles virus expressing the secreted form of E protein from a virulent strain of West Nile virus (Despres et al., 2005), a live attenuated WNV/Dengue 4 virus chimera (Pletnev et al., 2003), RepliVax WN, a defective pseudoinfectious West Nile virus lacking a functional capsid gene (Mason et al., 2006; Widman et al., 2008; Yamshchikov et al., 2004), an attenuated West Nile prototype virus (Yamshchikov et al., 2004) and a plasmid DNA vaccine containing the infectious full-length RNA genome of Kunjin (KUN) virus (Hall et al., 2003), a subtype of West Nile virus. In addition subunit vaccines including a bacterially expressed domain III of West Nile virus E protein (Chu et al., 2007; Martina et al., 2008) and a recombinant truncated E (trE) and NS1 protein construct expressed in Drosophila S2 cells (Lieberman et al., 2007; Watts et al., 2007) are under investigation.

As with Japanese encephalitis virus, the prospect for a human vaccine for West Nile virus infections is promising, with the leading candidates at various stages of clinical trials as well as a number of promising candidates still at the early developmental stage.

\subsubsection{Murray Valley encephalitis virus}

There is currently no vaccine to protect against infection with Murray Valley encephalitis, and given the limited distribution and low incidence of cases, it is possible that a specific commercial vaccine against Murray Valley encephalitis will not be developed. However, animal studies have suggested that immunization with a live chimeric anti-Japanese encephalitis vaccine (ChimeriVax-JE) may provide protection against the closely related Murray Valley encephalitis virus (Lobigs et al., 2009). However, preliminary animal based studies using Murray Valley encephalitis recombinant subviral particles (Kroeger \& McMinn, 2002) or E and NS1 proteins expressed in a recombinant vaccinia virus (Hall et al., 1996) have been undertaken which may possibly lead to the development of a specific Murray Valley encephalitis vaccine.

\subsubsection{St. Louis encephalitis virus}

There is currently no commercially licensed vaccine to protect against infection with St. Louis encephalitis virus. The development of possible vaccines follows closely the development of West Nile virus vaccines. Potential vaccine constructs evaluated at least in animal studies include chimeric yellow fever/ St. Louis encephalitis virus constructs consisting of the well characterized yellow fever vaccine strain YF-17D backbone with the pre-membrane and envelope coding sequences of a virulent (MSI-7) or an attenuated 
(CorAn9124) strain of St. Louis encephalitis virus (Pugachev et al., 2004) and a chimeric dengue serotype 4/ St. Louis encephalitis virus construct consisting of the dengue serotype 4 backbone and the pre-membrane and envelope coding sequences of Hubbard strain of St. Louis encephalitis virus (Blaney et al., 2008). In addition a prime/boost strategy using sequential immunization with a vaccinia virus expressing St. Louis encephalitis virus premembrane and envelope proteins followed by purified recombinant envelope protein (Venugopal et al., 1995) and a DNA vaccine candidate based upon expression of the St. Louis encephalitis virus pre-membrane and envelope proteins under control of the cytomegalovirus immediate-early promoter have been investigated in mice (Phillpotts et al., 1996).

\subsubsection{Louping ill virus}

Probably as a reflection of the extremely low incidence of Louping ill virus infections in humans, little vaccine development has taken place, although a vaccine for sheep has been in use in the United Kingdom since before 1935. The original vaccine was prepared from formalin inactivated virus grown in sheep brains, but this practice was halted when causal evidence of a link with spread of the sheep prion disease Scrapie was uncovered (Nathanson, 2007). The current sheep vaccine is made by formalin inactivation of virus grown in cultured cells. At this point it seems unlikely that a human vaccine will be developed.

\subsubsection{Powassan virus}

There is currently no vaccine to protect against infection with Powassan virus, and given the extremely small number of cases reported so far, it is somewhat unlikely that a concerted vaccine development program will be initiated, in the absence of a significant increase in the number of cases. It is possible that some degree of protection against Powassan virus infection may be induced by immunization with a vaccine developed against a different member of the tick-borne encephalitis group, but this remains speculative at the moment.

\subsubsection{Tick-borne encephalitis virus}

There are currently two vaccines available for prophylactic protection against Tick-borne encephalitis virus infections. These vaccines, FSME-Immun (Baxter, Austria) and Encepur (Novartis, Germany) are both formalin inactivated whole virus produced in primary chicken embryo fibroblasts and are distributed in adult and child formulations. FSMEImmun is derived from the Austrian Neudorfl strain, while Encepur is derived from the German K23 isolate. Both vaccines protect against all three subtypes (European, far-Eastern and Siberian) of Tick-borne encephalitis virus and are able to be administered in conventional and rapid immunization schedules, although evidence suggests that the conventional schedules offer better protection. Both vaccines have undergone considerable formulation changes since their original introduction as a consequence of adverse immunization events and as both viruses are manufactured using chicken eggs, the possibility of hypersensitivity reactions remains. Two further vaccines are available or undergoing trials in Russia, the KKhv and IPVE vaccines (Demicheli et al., 2009) but there are few if any reports in the English language literature about these formulations. Overall, vaccination coverage rates vary dramatically among Tick-borne encephalitis virus endemic countries, but where effective vaccination programs are in place as in Austria, a significant reduction in Tick-borne encephalitis virus incidence has been observed (Petri et al., 2010). However, significant numbers of hospitalizations still occur in endemic countries, despite the 
availability of vaccines which probably results from the high cost of the vaccines as well as the requirement for multiple booster shots to maintain effective protection (Widman et al., 2008).

Several studies have attempted to use the naturally attenuated Langat virus as the basis of a vaccine against Tick-borne encephalitis virus infection. These include large scale (more than 600,000 individuals) testing in the former USSR of the Yelantsev strain of Langat virus but due to an unacceptably high incidence of vaccine associated complications, this approach was discontinued. However, a Langat/Dengue 4 chimeric live vaccine which replaces the dengue serotype 4 pre-membrane and envelope proteins with the corresponding sequences from the Langat virus TP21 strain is currently under development (Pripuzova et al., 2009). Other potential live attenuated virus vaccine candidates include a recombinant vaccinia virus expressing the tick-borne virus non-structural NS1 protein (Aleshin et al., 2005), a vaccinia virus vector carrying the tick-borne encephalitis virus prM/E sequences (Holzer et al., 1999) and a self-replicating noninfectious Tick-borne encephalitis virus RNA vaccine based upon the Neudoerfl tick-borne encephalitis strain, but containing a large deletion of the sequences coding for the capsid protein (Aberle et al., 2005). Potential nucleic acid based (Aberle et al., 1999; Schmaljohn et al., 1997) and subunit vaccines are also at an early stage of development.

\subsection{Therapeutic agents}

Current treatment for all flavivirus infections is primarily supportive and orientated towards alleviating symptoms and there are no specific antivirals marketed to combat flaviviral infections. Small scale trials of existing antiviral agents such as ribavirin (Chowers et al., 2001) and interferon- $\alpha$ (Solomon et al., 2003) have proved disappointing. There are however a large number of compounds currently in the developmental pipeline targeted against a number of different processes in the flavivirus life cycle. In addition, therapeutic immunoglobulins have shown some promise in animal model systems of West Nile virus infection (Ben-Nathan et al., 2003; Oliphant et al., 2005). Current drug compound discovery primarily centers on inhibition of virus entry, replication and translation, polyprotein processing, virus assembly and cellular host proteins, and while drug development primarily focuses on a specific flavivirus, the hope is that a broad spectrum anti-flaviviral compound will be discovered. However, the apparent lack of efficacy of ribavirin and interferon- $\alpha$, towards West Nile virus, while these are effective treatments for infections with Hepatitis $\mathrm{C}$ virus which is a closely related member of the family Flaviviridae (genus Hepacivirus), suggests that this may be an unrealistic objective.

Potential entry inhibitors being evaluated include sulfated glycosaminoglycans, sulfated galactomannans and quinazolines which either directly interact with the virus to prevent binding to the cell, or interfere with the process of membrane fusion leaving the virus trapped at the cell surface. However, the wide sequence diversity of the flavivirus E protein suggests that these molecules may have a narrowly defined application. In addition, a significant amount of research has suggested that even a single flavivirus may use multiple proteins to enter into cells, and that these proteins may differ between different cell types. Of even greater concern are the several studies that imply multiple mechanisms of entry for some flaviviruses, in addition to endocytosis into clathrin coated pits (Acosta et al., 2009; Suksanpaisan et al., 2009), all of which may serve to make the initial host cell: virus interaction a less than desirable target.

Significant attention has focused therefore on the flaviviral proteins with enzymatic activity, namely the NS3 and NS5 proteins. The NS3 protein has both protease and helicase activities, 
while the NS5 protein has methyltransferase and RNA-dependent RNA polymerase activities. These proteins, from several different flaviviruses, have been cloned either as a complete functional unit of or as a sub-domain expressing a single activity in a number of reporter systems, and adapted to high throughput screening assays, allowing the assay of many thousands of potential compounds. There are several recent comprehensive reviews on the progress of anti-flavivirus drug development (Bollati et al., 2010; Noble et al., 2010; Parkinson \& Pryde, 2010; Pastorino et al., 2010; Paula et al., 2009).

\section{Conclusions}

The genus flavivirus contains some of the most important vector-borne human pathogens, which are widely distributed around the world. Several flaviviruses including some of the most important encephalitis causing viruses such as Japanese encephalitis virus, West Nile virus and Tick-borne encephalitis virus (both European and Far-Eastern) are considered to be emerging infectious diseases in that they have recently shown an increase in "incidence, impact or geographic range" (Jones et al., 2008). Increases in the geographic range of a vector borne disease may follow the natural expansion of a host species into new geographical locations, or, possibly sudden importation as a result of human activity (Pfeffer \& Dobler, 2010). However, the sudden and explosive epidemic of chikungunya virus (a member of the family Togaviridae, genus Alphavirus) infections in the Indian Ocean Islands, India and much of Southeast Asia (Staples et al., 2009) occurred largely as a result of the adaptation of the chikungunya virus to transmission by a new host (Aedes albopictus instead of Aedes aegypti) and spread internationally by infected humans. This was clearly illustrated by the outbreak of chikungunya fever in Italy in 2007, where the disease was imported by an infected but presumably pre-symptomatic traveler from India and the virus became established in the local Aedes albopictus population. As such, there are several potential mechanisms by which vector borne diseases may become established in new areas, exposing new populations to the hazards of these diseases.

Total eradication of the encephalitic flaviviruses seems highly unlikely. While it was possible to eliminate the Smallpox virus from nature, this virus was spread through direct contact with an infected person or with contaminated fluids or objects, and there is no natural reservoir for this virus apart from the human population. With flaviviruses, numerous natural host reservoirs exist in the wild, and transovarial transmission of both tick-borne and mosquito borne flaviviruses has been documented. Given the inability to eradicate these diseases from the wild, efforts to control these diseases and their transmission are focused on vector control policies as well as on prevention and cure of the disease where human infection does occur. Immunization clearly offers the best solution to prevention of these diseases in humans, and as has been seen in the previous section, effective vaccines for Japanese encephalitis and tick-borne encephalitis are already available, while vaccines for the remaining encephalitis causing diseases (with a few exceptions) are generally well advanced. As such research in vaccine development will be essentially focused on improvement, both with regards to lowering the incidence of adverse events, as well as reducing the cost of the vaccines. With effective vaccines, the critical issue is one of cost. Both tick- and mosquito borne encephalitic flaviviruses are common in the developing nations of the world, and the main mission will be to make the vaccines affordable for people in resource poor countries, and ensure the vaccine is delivered to susceptible population groups. This will also entail careful integration of the new vaccines with existing immunization programs. 
To date, drug development somewhat lags behind vaccine development and there are currently no specific anti-flaviviral drugs available, nor any drugs specifically designed to combat the consequences of encephalitic manifestations of the disease. However, the advent of new technologies has provided a significant boost to drug development programs although it remains to be seen whether this will genuinely result in new therapies and whether these potential drugs will be broad spectrum or specific to a particular virus species. This research however remains of vital importance. While vaccine programs are ideal for long-term disease control, vaccine development for flaviviruses takes years or decades for a safe, effective and cheap vaccine to be produced. In the event of a massive explosion of a previously unregarded flaviviral disease, a broad spectrum anti-flaviviral agent may be the only practical solution to reduce high levels of morbidity and mortality.

\section{Acknowledgement}

The author gratefully acknowledges the Office of the Higher Education Commission and Mahidol University under the National Research Universities Initiative, The Thailand Research Fund and The National Center for Genetic Engineering and Biotechnology, National Science and Technology Development Agency for support of his studies on the pathogenesis of arboviruses.

\section{References}

Aberle, J. H., Aberle S. W., Allison S. L., Stiasny K., Ecker M., Mandl C. W., Berger R., Heinz F. X. (1999). A DNA immunization model study with constructs expressing the tickborne encephalitis virus envelope protein $\mathrm{E}$ in different physical forms. J Immunol 163(12):6756-6761.

Aberle, J. H., Aberle S. W., Kofler R. M., Mandl C. W. (2005). Humoral and cellular immune response to RNA immunization with flavivirus replicons derived from tick-borne encephalitis virus. J Virol 79(24):15107-15113.

Acosta, E. G., Castilla V., Damonte E. B. (2009). Alternative infectious entry pathways for dengue virus serotypes into mammalian cells. Cell Microbiol 11(10):1533-1549.

Aleshin, S. E., Timofeev A. V., Khoretonenko M. V., Zakharova L. G., Pashvykina G. V., Stephenson J. R., Shneider A. M., Altstein A. D. (2005). Combined prime-boost vaccination against tick-borne encephalitis (TBE) using a recombinant vaccinia virus and a bacterial plasmid both expressing TBE virus non-structural NS1 protein. BMC Microbiol 5:45.

Allison, S. L., Schalich J., Stiasny K., Mandl C. W., Heinz F. X. (2001). Mutational evidence for an internal fusion peptide in flavivirus envelope protein E. J Virol 75(9):4268-4275.

Bakonyi, T., Hubalek Z., Rudolf I., Nowotny N. (2005). Novel flavivirus or new lineage of West Nile virus, central Europe. Emerg Infect Dis 11(2):225-231.

Ben-Nathan, D., Lustig S., Tam G., Robinzon S., Segal S., Rager-Zisman B. (2003). Prophylactic and therapeutic efficacy of human intravenous immunoglobulin in treating West Nile virus infection in mice. J Infect Dis 188(1):5-12.

Berthet, F. X., Zeller H. G., Drouet M. T., Rauzier J., Digoutte J. P., Deubel V. (1997). Extensive nucleotide changes and deletions within the envelope glycoprotein gene of Euro-African West Nile viruses. J Gen Virol 78 ( Pt 9):2293-2297.

Biedenbender, R., Bevilacqua J., Gregg A. M., Watson M., Dayan G. (2011). Phase II, randomized, double-blind, placebo-controlled, multicenter study to investigate the 
immunogenicity and safety of a West Nile virus vaccine in healthy adults. J Infect Dis 203(1):75-84.

Blaney, J. E., Jr., Speicher J., Hanson C. T., Sathe N. S., Whitehead S. S., Murphy B. R., Pletnev A. G. (2008). Evaluation of St. Louis encephalitis virus/dengue virus type 4 antigenic chimeric viruses in mice and rhesus monkeys. Vaccine 26(33):4150-4159.

Bollati, M., Alvarez K., Assenberg R., Baronti C., Canard B., Cook S., Coutard B., Decroly E., de Lamballerie X., Gould E. A., Grard G., Grimes J. M., Hilgenfeld R., Jansson A. M., Malet H., Mancini E. J., Mastrangelo E., Mattevi A., Milani M., Moureau G., Neyts J., Owens R. J., Ren J., Selisko B., Speroni S., Steuber H., Stuart D. I., Unge T., Bolognesi M. (2010). Structure and functionality in flavivirus NS-proteins: perspectives for drug design. Antiviral Res 87(2):125-148.

Centers for Disease Control and Prevention (CDC). (2003). Epidemic/epizootic West Nile virus in the United States: guidelines for surveillance, prevention, and control. www.cdc.gov/NCIDOD/DVBID/WESTNILE/resources/wnv-guidelines-apr-2001.pdf.

Chang, G. J. 1997. Molecular biology of dengue viruses. Gluber, D., Kuno G., editor. New York: CAB International. 175-198 p.

Charrel, R. N., Attoui H., Butenko A. M., Clegg J. C., Deubel V., Frolova T. V., Gould E. A., Gritsun T. S., Heinz F. X., Labuda M., Lashkevich V. A., Loktev V., Lundkvist A., Lvov D. V., Mandl C. W., Niedrig M., Papa A., Petrov V. S., Plyusnin A., Randolph S., Suss J., Zlobin V. I., de Lamballerie X. (2004). Tick-borne virus diseases of human interest in Europe. Clin Microbiol Infect 10(12):1040-1055.

Chen, Y., Maguire T., Hileman R. E., Fromm J. R., Esko J. D., Linhardt R. J., Marks R. M. (1997). Dengue virus infectivity depends on envelope protein binding to target cell heparan sulfate. Nat Med 3(8):866-871.

Chowers, M. Y., Lang R., Nassar F., Ben-David D., Giladi M., Rubinshtein E., Itzhaki A., Mishal J., Siegman-Igra Y., Kitzes R., Pick N., Landau Z., Wolf D., Bin H., Mendelson E., Pitlik S. D., Weinberger M. (2001). Clinical characteristics of the West Nile fever outbreak, Israel, 2000. Emerg Infect Dis 7(4):675-678.

Chu, J. H., Chiang C. C., Ng M. L. (2007). Immunization of flavivirus West Nile recombinant envelope domain III protein induced specific immune response and protection against West Nile virus infection. J Immunol 178(5):2699-2705.

Chu, J. J., Rajamanonmani R., Li J., Bhuvanakantham R., Lescar J., Ng M. L. (2005). Inhibition of West Nile virus entry by using a recombinant domain III from the envelope glycoprotein. J Gen Virol 86(Pt 2):405-412.

Crill, W. D., Chang G. J. (2004). Localization and characterization of flavivirus envelope glycoprotein cross-reactive epitopes. J Virol 78(24):13975-13986.

Crill, W. D., Roehrig J. T. (2001). Monoclonal antibodies that bind to domain III of dengue virus E glycoprotein are the most efficient blockers of virus adsorption to Vero cells. J Virol 75(16):7769-7773.

Demicheli, V., Debalini M. G., Rivetti A. (2009). Vaccines for preventing tick-borne encephalitis. Cochrane Database Syst Rev(1):CD000977.

Desai, A., Shankar S. K., Ravi V., Chandramuki A., Gourie-Devi M. (1995). Japanese encephalitis virus antigen in the human brain and its topographic distribution. Acta Neuropathol 89(4):368-373.

Despres, P., Combredet C., Frenkiel M. P., Lorin C., Brahic M., Tangy F. (2005). Live measles vaccine expressing the secreted form of the West Nile virus envelope glycoprotein protects against West Nile virus encephalitis. J Infect Dis 191(2):207-214. 
Dimitrov, D. S. (2004). Virus entry: molecular mechanisms and biomedical applications. Nat Rev Microbiol 2(2):109-122.

Ebel, G. D. (2010). Update on Powassan virus: emergence of a North American tick-borne flavivirus. Annu Rev Entomol 55:95-110.

Gajanana, A., Thenmozhi V., Samuel P. P., Reuben R. (1995). A community-based study of subclinical flavivirus infections in children in an area of Tamil Nadu, India, where Japanese encephalitis is endemic. Bull World Health Organ 73(2):237-244.

Gholam, B. I., Puksa S., Provias J. P. (1999). Powassan encephalitis: a case report with neuropathology and literature review. CMAJ 161(11):1419-1422.

Hall, R. A., Brand T. N., Lobigs M., Sangster M. Y., Howard M. J., Mackenzie J. S. (1996). Protective immune responses to the E and NS1 proteins of Murray Valley encephalitis virus in hybrids of flavivirus-resistant mice. J Gen Virol 77 ( Pt 6):1287-1294.

Hall, R. A., Nisbet D. J., Pham K. B., Pyke A. T., Smith G. A., Khromykh A. A. (2003). DNA vaccine coding for the full-length infectious Kunjin virus RNA protects mice against the New York strain of West Nile virus. Proc Natl Acad Sci U S A 100(18):10460-10464.

Halstead, S. B., Jacobson J. (2003). Japanese encephalitis. Adv Virus Res 61:103-138.

Halstead, S. B., Thomas S. J. (2010). New vaccines for Japanese encephalitis. Curr Infect Dis Rep 12(3):174-180.

Hayes, E. B., Sejvar J. J., Zaki S. R., Lanciotti R. S., Bode A. V., Campbell G. L. (2005). Virology, pathology, and clinical manifestations of West Nile virus disease. Emerg Infect Dis 11(8):1174-1179.

Heinz, F. X., Berger R., Tuma W., Kunz C. (1983). A topological and functional model of epitopes on the structural glycoprotein of tick-borne encephalitis virus defined by monoclonal antibodies. Virology 126(2):525-537.

Heinz, F. X., Roehring, J.T. 1990. Flaviviruses. vanRegen-Mortel, M. H. V., Neurath, A.R., editor. Amsterdam: Elsevier Science. 289-305 p.

Henchal, E. A., Putnak J. R. (1990). The dengue viruses. Clin Microbiol Rev 3(4):376-396.

Holzer, G. W., Remp G., Antoine G., Pfleiderer M., Enzersberger O. M., Emsenhuber W., Hammerle T., Gruber F., Urban C., Falkner F. G., Dorner F. (1999). Highly efficient induction of protective immunity by a vaccinia virus vector defective in late gene expression. J Virol 73(6):4536-4542.

Hung, J. J., Hsieh M. T., Young M. J., Kao C. L., King C. C., Chang W. (2004). An external loop region of domain III of dengue virus type 2 envelope protein is involved in serotypespecific binding to mosquito but not mammalian cells. J Virol 78(1):378-388.

Hurrelbrink, R. J., McMinn P. C. (2001). Attenuation of Murray Valley encephalitis virus by site-directed mutagenesis of the hinge and putative receptor-binding regions of the envelope protein. J Virol 75(16):7692-7702.

ICTV. (2011). ICTV Master Species List 2009 - Version 9. Date of Access: 12 February 2011, http://ictvonline.org/index.asp

Johnson, R. T., Burke D. S., Elwell M., Leake C. J., Nisalak A., Hoke C. H., Lorsomrudee W. (1985). Japanese encephalitis: immunocytochemical studies of viral antigen and inflammatory cells in fatal cases. Ann Neurol 18(5):567-573.

Jones, K. E., Patel N. G., Levy M. A., Storeygard A., Balk D., Gittleman J. L., Daszak P. (2008). Global trends in emerging infectious diseases. Nature 451(7181):990-993.

Kimura, T., Ohyama A. (1988). Association between the pH-dependent conformational change of West Nile flavivirus E protein and virus-mediated membrane fusion. J Gen Virol 69 ( Pt 6):1247-1254. 
Klasse, P. J., Bron R., Marsh M. (1998). Mechanisms of enveloped virus entry into animal cells. Adv Drug Deliv Rev 34(1):65-91.

Kroeger, M. A., McMinn P. C. (2002). Murray Valley encephalitis virus recombinant subviral particles protect mice from lethal challenge with virulent wild-type virus. Arch Virol 147(6):1155-1172.

Kuhn, R. J., Zhang W., Rossmann M. G., Pletnev S. V., Corver J., Lenches E., Jones C. T., Mukhopadhyay S., Chipman P. R., Strauss E. G., Baker T. S., Strauss J. H. (2002). Structure of Dengue Virus: Implications for Flavivirus Organization, Maturation, and Fusion. Cell 108(5):717-725.

Kumar, R., Mathur A., Singh K. B., Sitholey P., Prasad M., Shukla R., Agarwal S. P., Arockiasamy J. (1993). Clinical sequelae of Japanese encephalitis in children. Indian J Med Res 97:9-13.

Labuda, M., Randolph S. E. (1999). Survival strategy of tick-borne encephalitis virus: cellular basis and environmental determinants. Zentralbl Bakteriol 289(5-7):513-524.

Lanciotti, R. S., Roehrig J. T., Deubel V., Smith J., Parker M., Steele K., Crise B., Volpe K. E., Crabtree M. B., Scherret J. H., Hall R. A., MacKenzie J. S., Cropp C. B., Panigrahy B., Ostlund E., Schmitt B., Malkinson M., Banet C., Weissman J., Komar N., Savage H. M., Stone W., McNamara T., Gubler D. J. (1999). Origin of the West Nile virus responsible for an outbreak of encephalitis in the northeastern United States. Science 286(5448):2333-2337.

Li, L., Lok S. M., Yu I. M., Zhang Y., Kuhn R. J., Chen J., Rossmann M. G. (2008). The flavivirus precursor membrane-envelope protein complex: structure and maturation. Science 319(5871):1830-1834.

Lieberman, M. M., Clements D. E., Ogata S., Wang G., Corpuz G., Wong T., Martyak T., Gilson L., Coller B. A., Leung J., Watts D. M., Tesh R. B., Siirin M., Travassos da Rosa A., Humphreys T., Weeks-Levy C. (2007). Preparation and immunogenic properties of a recombinant West Nile subunit vaccine. Vaccine 25(3):414-423.

Lobigs, M., Larena M., Alsharifi M., Lee E., Pavy M. (2009). Live chimeric and inactivated Japanese encephalitis virus vaccines differ in their cross-protective values against Murray Valley encephalitis virus. J Virol 83(6):2436-2445.

Mandl, C. W. (2005). Steps of the tick-borne encephalitis virus replication cycle that affect neuropathogenesis. Virus Res 111(2):161-174.

Mandl, C. W., Guirakhoo F., Holzmann H., Heinz F. X., Kunz C. (1989). Antigenic structure of the flavivirus envelope protein $\mathrm{E}$ at the molecular level, using tick-borne encephalitis virus as a model. J Virol 63(2):564-571.

Mansfield, K. L., Johnson N., Phipps L. P., Stephenson J. R., Fooks A. R., Solomon T. (2009). Tick-borne encephalitis virus - a review of an emerging zoonosis. J Gen Virol $90(\mathrm{Pt}$ 8):1781-1794.

Marfin, A. A., Petersen L. R., Eidson M., Miller J., Hadler J., Farello C., Werner B., Campbell G. L., Layton M., Smith P., Bresnitz E., Cartter M., Scaletta J., Obiri G., Bunning M., Craven R. C., Roehrig J. T., Julian K. G., Hinten S. R., Gubler D. J. (2001). Widespread West Nile virus activity, eastern United States, 2000. Emerg Infect Dis 7(4):730-735.

Marsh, M. (1984). The entry of enveloped viruses into cells by endocytosis. Biochem J 218:1-10.

Martin, J. E., Pierson T. C., Hubka S., Rucker S., Gordon I. J., Enama M. E., Andrews C. A., Xu Q., Davis B. S., Nason M., Fay M., Koup R. A., Roederer M., Bailer R. T., Gomez P. L., Mascola J. R., Chang G. J., Nabel G. J., Graham B. S. (2007). A West Nile virus DNA vaccine induces neutralizing antibody in healthy adults during a phase 1 clinical trial. J Infect Dis 196(12):1732-1740. 
Martina, B. E., Koraka P., van den Doel P., van Amerongen G., Rimmelzwaan G. F., Osterhaus A. D. (2008). Immunization with West Nile virus envelope domain III protects mice against lethal infection with homologous and heterologous virus. Vaccine 26(2):153-157.

Mason, P. W., Shustov A. V., Frolov I. (2006). Production and characterization of vaccines based on flaviviruses defective in replication. Virology 351(2):432-443.

Misra, U. K., Kalita J. (2010). Overview: Japanese encephalitis. Prog Neurobiol 91(2):108-120.

Modis, Y., Ogata S., Clements D., Harrison S. C. (2003). A ligand-binding pocket in the dengue virus envelope glycoprotein. Proc Natl Acad Sci U S A 100(12):6986-6991.

Monath, T. P. (2001). Yellow fever: an update. Lancet Infect Dis 1(1):11-20.

Monath, T. P., Cropp C. B., Harrison A. K. (1983). Mode of entry of a neurotropic arbovirus into the central nervous system. Reinvestigation of an old controversy. Lab Invest 48(4):399-410.

Morrey, J. D., Olsen A. L., Siddharthan V., Motter N. E., Wang H., Taro B. S., Chen D., Ruffner D., Hall J. O. (2008). Increased blood-brain barrier permeability is not a primary determinant for lethality of West Nile virus infection in rodents. J Gen Virol 89(Pt 2):467-473.

Nathanson, N. 2007. Epidemiology. In: Knipe, D. M., Howley P. M., editors. Field's virology: Lippincott Williams \& Wilkins. p 423-446.

Noble, C. G., Chen Y. L., Dong H., Gu F., Lim S. P., Schul W., Wang Q. Y., Shi P. Y. (2010). Strategies for development of Dengue virus inhibitors. Antiviral Res 85(3):450-462.

Ogawa, M., Okubo H., Tsuji Y., Yasui N., Someda K. (1973). Chronic progressive encephalitis occurring 13 years after Russian spring-summer encephalitis. J Neurol Sci 19(3):363-373.

Oliphant, T., Engle M., Nybakken G. E., Doane C., Johnson S., Huang L., Gorlatov S., Mehlhop E., Marri A., Chung K. M., Ebel G. D., Kramer L. D., Fremont D. H., Diamond M. S. (2005). Development of a humanized monoclonal antibody with therapeutic potential against West Nile virus. Nat Med 11(5):522-530.

Parkinson, T., Pryde D. C. (2010). Small molecule drug discovery for Dengue and West Nile viruses: Applying experience from hepatitis C virus. Future Medicinal Chemistry 2(7):1181-1203.

Pastorino, B., Nougairede A., Wurtz N., Gould E., de Lamballerie X. (2010). Role of host cell factors in flavivirus infection: Implications for pathogenesis and development of antiviral drugs. Antiviral Res 87(3):281-294.

Paula, T., Pablo R., Eugenia V., Pablo B., Sabino P., Jose M., Antonio M., Dolores H. M., Pablo L., Javier G. S., Vincente S. (2009). New drug targets for hepatitis C and other Flaviviridae viruses. Infect Disord Drug Targets 9(2):133-147.

Perera, R., Kuhn R. J. (2008). Structural proteomics of dengue virus. Curr Opin Microbiol 11(4):369-377.

Petri, E., Gniel D., Zent O. (2010). Tick-borne encephalitis (TBE) trends in epidemiology and current and future management. Travel Med Infect Dis 8(4):233-245.

Pfeffer, M., Dobler G. (2010). Emergence of zoonotic arboviruses by animal trade and migration. Parasit Vectors 3(1):35.

Phillpotts, R. J., Venugopal K., Brooks T. (1996). Immunisation with DNA polynucleotides protects mice against lethal challenge with St. Louis encephalitis virus. Arch Virol 141(3-4):743-749.

Platonov, A. E., Shipulin G. A., Shipulina O. Y., Tyutyunnik E. N., Frolochkina T. I., Lanciotti R. S., Yazyshina S., Platonova O. V., Obukhov I. L., Zhukov A. N., Vengerov Y. Y., Pokrovskii V. I. (2001). Outbreak of West Nile virus infection, Volgograd Region, Russia, 1999. Emerg Infect Dis 7(1):128-132. 
Pletnev, A. G., Claire M. S., Elkins R., Speicher J., Murphy B. R., Chanock R. M. (2003). Molecularly engineered live-attenuated chimeric West Nile/dengue virus vaccines protect rhesus monkeys from West Nile virus. Virology 314(1):190-195.

Pripuzova, N. S., Tereshkina N. V., Gmyl L. V., Dzhivanyan T. I., Rumyantsev A. A., Romanova L., Mustafina A. N., Lashkevich V. A., Karganova G. G. (2009). Safety evaluation of chimeric Langat/Dengue 4 flavivirus, a live vaccine candidate against tick-borne encephalitis. J Med Virol 81(10):1777-1785.

Pugachev, K. V., Guirakhoo F., Mitchell F., Ocran S. W., Parsons M., Johnson B. W., Kosoy O. L., Lanciotti R. S., Roehrig J. T., Trent D. W., Monath T. P. (2004). Construction of yellow fever/St. Louis encephalitis chimeric virus and the use of chimeras as a diagnostic tool. Am J Trop Med Hyg 71(5):639-645.

Rey, F. A., Heinz F. X., Mandl C., Kunz C., Harrison S. C. (1995). The envelope glycoprotein from tick-borne encephalitis virus at 2 A resolution. Nature 375(6529):291-298.

Roehrig, J. T., Mathews J. H., Trent D. W. (1983). Identification of epitopes on the E glycoprotein of Saint Louis encephalitis virus using monoclonal antibodies. Virology 128(1):118-126.

Rosen, L. (1986). The natural history of Japanese encephalitis virus. Annu Rev Microbiol 40:395-414.

Russell, P. K., Brandt W. E., Dalrymple J. M., editors. 1980. Chemical and antigenic structure of flaviviruses. New York: Academic Press. 503-529 p.

Sabin, A. B., Schlesinger R. W. (1945). Production of Immunity to Dengue with Virus Modified by Propagation in Mice. Science 101(2634):640-642.

Savage, H. M., Ceianu C., Nicolescu G., Karabatsos N., Lanciotti R., Vladimirescu A., Laiv L., Ungureanu A., Romanca C., Tsai T. F. (1999). Entomologic and avian investigations of an epidemic of West Nile fever in Romania in 1996, with serologic and molecular characterization of a virus isolate from mosquitoes. Am J Trop Med Hyg 61(4):600-611.

Schmaljohn, C., Vanderzanden L., Bray M., Custer D., Meyer B., Li D., Rossi C., Fuller D., Fuller J., Haynes J., Huggins J. (1997). Naked DNA vaccines expressing the prM and $\mathrm{E}$ genes of Russian spring summer encephalitis virus and Central European encephalitis virus protect mice from homologous and heterologous challenge. $J$ Virol 71(12):9563-9569.

Sharma, S., Mathur A., Prakash V., Kulshreshtha R., Kumar R., Chaturvedi U. C. (1991). Japanese encephalitis virus latency in peripheral blood lymphocytes and recurrence of infection in children. Clin Exp Immunol 85(1):85-89.

Solomon, T. (2004). Flavivirus encephalitis. N Engl J Med 351(4):370-378.

Solomon, T., Dung N. M., Kneen R., Gainsborough M., Vaughn D. W., Khanh V. T. (2000). Japanese encephalitis. J Neurol Neurosurg Psychiatry 68(4):405-415.

Solomon, T., Dung N. M., Kneen R., Thao le T. T., Gainsborough M., Nisalak A., Day N. P., Kirkham F. J., Vaughn D. W., Smith S., White N. J. (2002). Seizures and raised intracranial pressure in Vietnamese patients with Japanese encephalitis. Brain 125(Pt 5):1084-1093.

Solomon, T., Dung N. M., Wills B., Kneen R., Gainsborough M., Diet T. V., Thuy T. T., Loan H. T., Khanh V. C., Vaughn D. W., White N. J., Farrar J. J. (2003). Interferon alfa-2a in Japanese encephalitis: a randomised double-blind placebo-controlled trial. Lancet 361(9360):821-826.

Srey, V. H., Sadones H., Ong S., Mam M., Yim C., Sor S., Grosjean P., Reynes J. M. (2002). Etiology of encephalitis syndrome among hospitalized children and adults in Takeo, Cambodia, 1999-2000. Am J Trop Med Hyg 66(2):200-207. 
Staples, J. E., Breiman R. F., Powers A. M. (2009). Chikungunya fever: an epidemiological review of a re-emerging infectious disease. Clin Infect Dis 49(6):942-948.

Suksanpaisan, L., Susantad T., Smith D. R. (2009). Characterization of dengue virus entry into HepG2 cells. J Biomed Sci 16:17.

Tsai, T., Popovici F., Cernescu C., Campbell G., Nedelcu N. (1998). West Nile encephalitis epidemic in southeastern Romania. Lancet 352:767-771.

Tsai, T. F. (2000). New initiatives for the control of Japanese encephalitis by vaccination: minutes of a WHO/CVI meeting, Bangkok, Thailand, 13-15 October 1998. Vaccine 18 Suppl 2:1-25.

Tunkel, A. R., Glaser C. A., Bloch K. C., Sejvar J. J., Marra C. M., Roos K. L., Hartman B. J., Kaplan S. L., Scheld W. M., Whitley R. J. (2008). The management of encephalitis: clinical practice guidelines by the Infectious Diseases Society of America. Clin Infect Dis 47(3):303-327.

Twiddy, S. S., Woelk C. H., Holmes E. C. (2002). Phylogenetic evidence for adaptive evolution of dengue viruses in nature. J Gen Virol 83(Pt 7):1679-1689.

Venugopal, K., Jiang W. R., Gould E. A. (1995). Immunity to St. Louis encephalitis virus by sequential immunization with recombinant vaccinia and baculovirus derived PrM/E proteins. Vaccine 13(11):1000-1005.

Volk, D. E., Beasley D. W., Kallick D. A., Holbrook M. R., Barrett A. D., Gorenstein D. G. (2004). Solution structure and antibody binding studies of the envelope protein domain III from the New York strain of West Nile virus. J Biol Chem 279(37):3875538761.

Wang, T., Town T., Alexopoulou L., Anderson J. F., Fikrig E., Flavell R. A. (2004). Toll-like receptor 3 mediates West Nile virus entry into the brain causing lethal encephalitis. Nat Med 10(12):1366-1373.

Watts, D. M., Tesh R. B., Siirin M., Rosa A. T., Newman P. C., Clements D. E., Ogata S., Coller B. A., Weeks-Levy C., Lieberman M. M. (2007). Efficacy and durability of a recombinant subunit West Nile vaccine candidate in protecting hamsters from West Nile encephalitis. Vaccine 25(15):2913-2918.

Widman, D. G., Frolov I., Mason P. W. (2008). Third-generation flavivirus vaccines based on single-cycle, encapsidation-defective viruses. Adv Virus Res 72:77-126.

World Health Organization. (2006). Vector-Borne Viral Infections Tick-borne encephalitis. http://www.who.int/vaccine_research/diseases/vector/en/print.html.

Wu, S. C., Chiang J. R., Lin C. W. (2004). Novel cell adhesive glycosaminoglycan-binding proteins of Japanese encephalitis virus. Biomacromolecules 5(6):2160-2164.

Yamshchikov, G., Borisevich V., Seregin A., Chaporgina E., Mishina M., Mishin V., Kwok C. W., Yamshchikov V. (2004). An attenuated West Nile prototype virus is highly immunogenic and protects against the deadly NY99 strain: a candidate for live WN vaccine development. Virology 330(1):304-312.

Yu, I. M., Holdaway H. A., Chipman P. R., Kuhn R. J., Rossmann M. G., Chen J. (2009). Association of the pr peptides with dengue virus at acidic $\mathrm{pH}$ blocks membrane fusion. J Virol 83(23):12101-12107. 


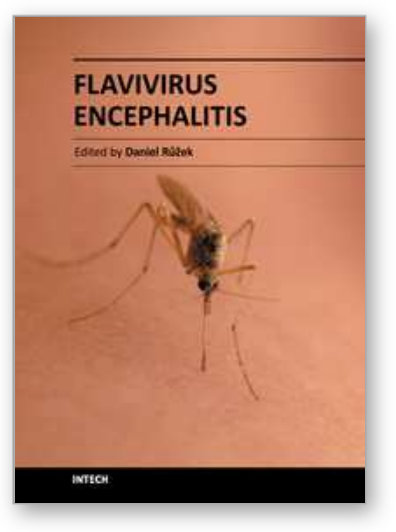

\author{
Flavivirus Encephalitis \\ Edited by Dr. Daniel Ruzek
}

ISBN 978-953-307-669-0

Hard cover, 478 pages

Publisher InTech

Published online 30, September, 2011

Published in print edition September, 2011

Encephalitis is an inflammation of the brain tissue associated with clinical evidence of brain dysfunction. The disease is of high public health importance worldwide due to its high morbidity and mortality. Flaviviruses, such as tick-borne encephalitis virus, Japanese encephalitis virus, Murray Valley encephalitis virus, or St. Louis encephalitis virus, represent important causative agents of encephalitis in humans in various parts of the world. The book Flavivirus Encephalitis provides the most recent information about selected aspects associated with encephalitic flaviviruses. The book contains chapters that cover a wide spectrum of subjects including flavivirus biology, virus-host interactions, role of vectors in disease epidemiology, neurological dengue, and West Nile encephalitis. Special attention is paid to tick-borne encephalitis and Japanese encephalitis viruses. The book uniquely combines up-to-date reviews with cutting-edge original research data, and provides a condensed source of information for clinicians, virologists, pathologists, immunologists, as well as for students of medicine or life sciences.

\title{
How to reference
}

In order to correctly reference this scholarly work, feel free to copy and paste the following:

Duncan R. Smith (2011). Encephalitic Flaviviruses, Flavivirus Encephalitis, Dr. Daniel Ruzek (Ed.), ISBN: $978-$ 953-307-669-0, InTech, Available from: http://www.intechopen.com/books/flavivirus-encephalitis/encephaliticflaviviruses

\section{INTECH}

open science | open minds

\section{InTech Europe}

University Campus STeP Ri

Slavka Krautzeka 83/A

51000 Rijeka, Croatia

Phone: +385 (51) 770447

Fax: +385 (51) 686166

www.intechopen.com

\section{InTech China}

Unit 405, Office Block, Hotel Equatorial Shanghai

No.65, Yan An Road (West), Shanghai, 200040, China 中国上海市延安西路65号上海国际贵都大饭店办公楼405单元

Phone: +86-21-62489820

Fax: $+86-21-62489821$ 
(C) 2011 The Author(s). Licensee IntechOpen. This chapter is distributed under the terms of the Creative Commons Attribution-NonCommercialShareAlike-3.0 License, which permits use, distribution and reproduction for non-commercial purposes, provided the original is properly cited and derivative works building on this content are distributed under the same license. 